' Pour moi, celui auquel m'unissaient, nécessairement, tant de liens, depuis une même et dévorante curiosité pour les choses de l'Afrique, jusqu'à une communion plus profonde encore dans le domaine de celles de l'âme, fut toujours le collaborateur le plus solide, celui en qui je pouvais me reposer dans la plus parfaite confiance, sachant que sa grande maturité d'esprit, son équilibre, sa pondération, sa puissance de travail seraient, quand il prenait en mon absence la direction de la " maison", le gage d'une action efficace et prudente. A la tâche choisie, ou plus souvent, hélas, imposée, il se donnait sans réserve et l'exécutait avec une apparente impassibilité, sans bousculade, sans sautes d'humeur, sans inutiles tempêtes. "Apparente" ai-je dit, car je sais, comme le savent ses intimes, quel représentaient pour lui, comme pour tous ceux qui prennent leur tâche pleinement au sérieux, ses périodes de direction.

'Comme il soupirait alors après la possibilité de retourner à de plus professionnelles, de plus techniques activités, au travail sur le terrain en particulier.

"Il n'est pas douteux que la " maison", qui exige beaucoup de ses vrais amis, a demandé à Jacques Richard-Molard une part importante d'un temps que l'on eût pu souhaiter consacré à la recherche. Elle lui doit, outre une large tranche de besogne administrative, la mise en route de la Section de géographie, avec celle des cartes ethniques et démographiques et de l'atlas ouest-africain, une véritable résurrection du Bulletin, devenu seulement depuis la guerre ce qu'il devait être: une revue scientifique africaine, subștantielle, nourrie, vivante.

'Disparu trop tôt, notre ami n'aura certes pas pu donner, dans la discipline de son choix, sa mesure. Les riches synthèses qu'il nous promettait, dans le double domaine de la morphologie et de la géographie humaine, sur les Rivières du Sud, le Fouta-Djallon, la dorsale Loma-Man ne verront jamais le jour. Pas plus que ce vaste commentaire entrepris sur la feuille I de la carte ethno-démographique au r.000.000è. Peut-être un certain nombre de pages inédites pourront-elles être sauvées.

'L'œuvre publiée ne peut que faire plus cruellement déplorer que l'essor scientifique de celui qui fut devenu, rapidement, un maître se soit vu si prématurément interrompu.'

\title{
African Music Transcription Library
}

THE first catalogue of the African Music Transcription Library, issued in July I 951 , contains an annotated list of 350 gramophone records of African and semi-African music recorded in various parts of Africa by 'African Music Research' under the direction of Hugh Tracey, founder and director of the African Music Society. The areas covered include Uganda, Tanganyika, Kenya, Ruanda-Urundi, Congo, French Equatorial Africa, Northern Rhodesia, Zanzibar, Nyasaland, Moçambique, Angola, Bechuanaland, and South Africa.

The catalogue is divided into sections based on linguistic groups, each section being prefaced by a short note on the people, their location, history, and the special characteristics of their music. The records are mainly of vocal music-praise-songs, love-songs, drinkingsongs, \&c., sometimes with instrumental accompaniment; some are dance-songs, accompanied by rattles, drums, or clappers. There are several records of the Chopi $N g o d o$ (orchestral dances) played by a xylophone orchestra and rattles (see Chopi Musicians, by H. Tracey, O.U.P. for International African Institute, 1948).

A few records of music by African composers, set to Portuguese and Latin words, are included, in particular portions of a Mass, 'Missa Katanga', composed by Joseph Kiwele and sung by the Chanteurs à la Croix de Cuivre at Élisabethville.

The catalogue is illustrated by drawings and photographs of African musical instruments, musicians, and dancers, and includes an alphabetical index of languages. Copies of the catalogue, as well as records, may be obtained from : The Director, African Music Transcription Library, P.O. Box 6216, Johannesburg. 